Received: 24 December 2018, Revised: 14 January 2019

Accepted: 23 January 2019, Published: 28 January 2019

Available online at: http://e-journal.unair.ac.id/index.php/IMHSJ

\title{
HUBUNGAN LAMA PAPARAN TELEVISI TERHADAP PERKEMBANGAN MOTORIK HALUS BALITA
}

\section{RELATION BETWEEN TELEVISION EXPOSURE AND TODDLER FINE MOTOR DEVELOPMENT}

\author{
Pingkan Fredelia Lontoh ${ }^{1}$, Ahmad Suryawan' ${ }^{2}$ Sri Utami ${ }^{2}$
}

1. Program Studi Pendidikan Bidan, Fakultas Kedokteran, Universitas

Airlangga

2. Fakultas Kedokteran, Universitas Airlangga

Alamat korespondensi:

Bumi Suko Indah B2-21, Sidoarjo, Jawa Timur, Indonesia

Email: pingkan.fredelia.lontoh-2017@ffk.unair.ac.id

\begin{abstract}
Abstrak
Latar belakang: Televisi merupakan salah satu inovasi teknologi yang sering digunakan oleh setiap orang tidak terkecuali anak balita. Menghabiskan banyak waktu pada tayangan televisi membuat anak-anak kehilangan kesempatan untuk mengeksplor lingkungan dan bermain dengan temanteman sebayanya sehingga berdampak pada kemampuan motorik anak. Tujuan: Mengetahui hubungan antara lama paparan televisi dengan perkembangan motorik halus anak usia 3-5 tahun. Metode: Penelitian analitik observasional dengan pendekatan cross sectional pada balita usia 3-5 tahun di wilayah kerja Puskesmas Kenjeran Surabaya dengan menggunakan purposive sampling. Lama paparan televisi diukur menggunakan lembar pengumpul data sedangkan perkembangan motorik halus diukur menggunakan KPSP aspek motorik halus. Analisis data menggunakan chi square $(p<0,05)$. Hasil: sebanyak 108 balita yang ikut serta dalam penelitian. Anak yang menonton $>2 \mathrm{jam} /$ hari sebagian besar lulus perkembangan motorik halus. Hasil uji chi-square menunjukkan adanya hubungan antara lama durasi paparan televisi dengan kemampuan motorik halus $(p=0,042)$. Kesimpulan: menonton televisi yang tidak terkendali dapat membawa dampak buruk bagi perkembangan motorik halus, diperlukan peran orangtua dalam mengawasi dan membatasi paparan televisi pada anak.
\end{abstract}

Kata kunci : paparan televisi, motorik halus, balita.

\begin{abstract}
Background: Television is one of the technological innovations that is often used by everyone is no exception for toddlers. Spending a lot of time on television shows makes children lose the opportunity to explore the environment and play with peers so as to impact the child's motor skills. Objectives: Know the relationship between prolonged television exposure with fine motor development of children aged 3-5 years. Method: Observational analytic research with cross sectional approach in toddlers aged 3-5 years in the working area of Kenjeran Surabaya by using purposive sampling. Prolonged television exposure was measured using a data collector sheet while smooth motorik developments were measured using KPSP fine motor aspects. Data analysis using Chi Square $(P<0.05)$. Results: As many as 108 toddlers participating in the study. Children watching $>2$ hours/day mostly pass fine motor development. The chi-square test results indicate the relationship between the length of the duration of television exposure with fine motor capability $(P=0,042)$. Conclusion: An uncontrolled television watch can bring a bad impact to the smooth motorik developments, required parental role in supervising and restricting television exposure in children.
\end{abstract}

Keywords: television exposure, fine motor, toddler. 


\section{PENDAHULUAN}

Dibandingkan dengan anak-anak pada satu dekade lalu, saat ini anak-anak memiliki akses yang mudah terhadap perangkat media seperti televisi, smartphone, tabelt, dll. Penelitian Lin, 2015 membuktikan bahwa anak-anak yang tidak diasuh langsung oleh orang tua, menghabiskan lebih banyak waktu untuk menonton televisi dibandingkan dengan anak-anak yang diasuh langsung oleh orangtua mereka, salah satu faktor yang mempengaruhi adalah posisi anak dalam keluarga. Anak tunggal dalam keluarga menjadi kesayangan dan diberi perlakuan berlebih baik oleh orangtua maupun nenek dan kakek sewaktu menonton televisi (Lin, Cherng, Chen, \& Chen, 2015).

Menurut survey yang dilakukan oleh KPI sebanyak 40\% penonton televisi merupakan anak-anak. Anak-anak Indonesia ternyata memiliki kebiasaan menonton televisi paling lama dengan lama waktu menonton selama $35 \mathrm{jam} /$ minggu. Menonton televisi merupakan kegiatan pasif yang dapat menghabiskan banyak waktu sehingga anak kehilangan kesempatan untuk melakukan aktifitas lain seperti bermain, berolahraga, dan mengeksplorasi lingkungan sekitarnya sebagai bentuk pengembangan diri. Terlalu banyak paparan televisi pada usia muda memiliki beberapa efek negatif pada anak yang berkaitan dengan perhatian yang buruk akan sekitarnya, kurangnya kontrol perilaku, gangguan perkembangan kemampuan kognitif, keterlambatan berbahasa, obesitas, dan gangguan tidur (Bruni, 2015; Burki, 2018; Kostyrka-allchorne, Cooper, \& Simpson, 2017).

Kurangnya aktifitas fisik pada anak yang menghabiskan banyak waktu didepan televisi berdampak pada kemampuan motorik, anak-anak yang melewatkan waktunya tanpa melakukan aktifitas fisik mungkin ketinggalan peluang dalam mengejar tugas perkembangan motoriknya.

\section{METODE}

Penelitian ini merupakan penelitian analitik observasional dengan pendekatan crosssectional. Penelitian ini dilakukan di wilayah kerja Puskesmas Kenjeran Surabaya pada tanggal 29 April - 24 Mei 2019. Sampel diambil dengan menggunakan purposive sampling. Jumlah sampel dalam penelitian ini berjumlah 108 anak usia 3-5 tahun yang datang ke posyandu di wilayah kerja Puskesmas 
Kenjeran Surabaya dan sesuai dengan kriteria inklusi serta eksklusi yang telah ditentukan.

Kriteria inklusi adalah balita usia 3-5 tahun yang dirumahnya memiliki televisi dan datang ke posyandu yang lahir aterm ( $\geq 37$ minggu) dengan berat lahir normal (2500-3500 gr) dan tidak sedang dalam keadaan sakit serta orangtua balita bersedia menjadi responden. Kriteria eklusi adalah anak yang memiliki cacat kongenital atau mengalami kelainan kongenital, anak yang memiliki riwayat penyakit yang bisa mempengaruhi perkembangan motorik.

Teknik pengumpulan data dilakukan dengan meminta orangtua/ pengasuh untuk mengisi lembar pengumpulan data untuk mengetahui lama durasi menonton televisi pada anak. Sementara data perkembangan anak diambil dengan melakukan pemeriksaan perkembangan menggunakan formulir KPSP bersama petugas kesehatan terlatih dari Puskesmas Kenjeran Surabaya. Data yang telah diperoleh dilakukan analisis menggunakan chi-square. Penelitian ini telah mendapatkan sertifikat persetujuan dari komite etik Universitas Airlangga Surabaya.

Tabel 1 Definisi operasional variabel

\begin{tabular}{|c|c|c|c|c|}
\hline Variabel & $\begin{array}{c}\text { Definisi } \\
\text { Operasional }\end{array}$ & Alat ukur & Skala & $\begin{array}{c}\text { Skor/ } \\
\text { Klasifikasi } \\
\end{array}$ \\
\hline $\begin{array}{l}\text { Variabel Independen: } \\
\text { Paparan televisi }\end{array}$ & \begin{tabular}{lr}
\multicolumn{2}{l}{ Lamanya } \\
yang dihabiskan \\
anak untuk \\
menonton televisi \\
setiap hari tanpa \\
mempertimbangkan \\
pendampingan dari \\
orangtua.
\end{tabular} & $\begin{array}{l}\text { Lembar } \\
\text { kuesioner }\end{array}$ & Ordinal & $\begin{array}{l}1: \leq 2 \text { jam } \\
2:>2 \text { jam }\end{array}$ \\
\hline $\begin{array}{l}\text { Variabel dependen: } \\
\text { - Perkembangan } \\
\text { kemampuan } \\
\text { motorik kasar }\end{array}$ & $\begin{array}{l}\text { Kemampuan anak } \\
\text { untuk melakukan } \\
\text { gerakan yang } \\
\text { terkoordinasi } \\
\text { dengan } \\
\text { menggunakan otot- } \\
\text { otot besar. }\end{array}$ & $\begin{array}{l}\text { Kuesioner Pra } \\
\text { Skrining } \\
\text { Pertumbuhan } \\
\text { (KPSP) aspek } \\
\text { motorik kasar } \\
\text { dan motorik } \\
\text { halus. }\end{array}$ & Nominal & $\begin{array}{l}\text { 1: Lulus, bila orangtua/ } \\
\text { pengasuh menjawab } \\
\text { "YA" pada semua } \\
\text { pertanyaan KPSP } \\
\text { aspek motorik sesuai } \\
\text { dengan usia anak }\end{array}$ \\
\hline $\begin{array}{l}\text { - Perkembangan } \\
\text { kemampuan } \\
\text { motorik halus }\end{array}$ & $\begin{array}{l}\text { Kemampuan anak } \\
\text { dalam melakukan } \\
\text { gerakan kecil yang } \\
\text { melibatkan } \\
\text { koordinasi cermat } \\
\text { antara otot-otot } \\
\text { kecil. }\end{array}$ & & & $\begin{array}{l}\text { 2: Belum lulus, bila } \\
\text { orangtua/pengasuh } \\
\text { menjawab "TIDAK" } \\
\text { pada salah satu atau } \\
\text { lebih dari pertanyaan } \\
\text { KPSP aspek motorik } \\
\text { sesuai usia anak }\end{array}$ \\
\hline
\end{tabular}


Pengumpulan data dilakukan pada bulan April-Mei 2019. Data diambil pada tiap posyandu yang ada di wilayah kerja Puskesmas Kenjeran Surabaya. Pengolahan data dilakukan dengan editing, coding, data entry, dan cleaning. Data yang sudah terkumpul dan diolah kemudian dianalisis menggunakan analisis univariat dan bivariate menggunakan uji chi-square dengan bantuan software SPSS.

\section{HASIL DAN PEMBAHASAN}

Responden penelitian didapatkan 108 orang dari 2016 balita usia 3-5 tahun yang memenuhi kriteria inklusi. Responden sebagian besar berada pada kisaran usia 4 tahun yaitu 37 (34,3\%). Responden yang berjenis kelamin laki-laki 66 (61,1\%), perempuan $42(38,9 \%)$. Lima puluh lima orang responden $(50,9 \%)$ menonton televisi $\leq 2 \mathrm{jam} /$ hari dan $53(49,1 \%)$ responden menonton televisi $>2 \mathrm{jam} / \mathrm{hari}$. Pendidikan terakhir ibu responden 63 (58,3\%) SMA dan 71 (65,7\%) tidak bekerja. Sembilan puluh responden $(83,3 \%)$ didampingi oleh orangtua ketika menonton televisi, dan 6 responden $(5,6 \%)$ tidak pernah didampingi oleh orangtua/ pengasuh saat menonton televisi (Tabel 2).

\section{Tabel 2 Karakteristik Responden}

\begin{tabular}{lcc}
\hline Karakteristik responden & Jumlah (n) & Presentase (\%) \\
\hline Usia (tahun) & 20 & 18,5 \\
3 & 26 & 24,1 \\
3,6 & 37 & 34,4 \\
4 & 16 & 14,8 \\
4,6 & 9 & 8,3 \\
5 & & \\
Jenis Kelamin & 66 & 61.1 \\
Laki-laki & 42 & 38,9 \\
Perempuan & & \\
Pendidikan terakhir ibu & 16 & 14,8 \\
SD & 24 & 22,2 \\
SMP & 63 & 58,3 \\
SMA & 4 & 3,7 \\
Perguruan tinggi & 1 & 0,9 \\
Tidak sekolah & & \\
Pekerjaan ibu & 71 & 65,7 \\
IRT & 37 & 34,3 \\
Swasta & & 14,8 \\
Waktu menonton televisi & 16 & 6,5 \\
Pagi, siang, sore & 7 & 6,5 \\
Pagi, siang & 7 & 13 \\
Siang, sore & 14 & 34,3 \\
Pagi, sore & 37 & \\
Pagi & & \\
\hline
\end{tabular}




\begin{tabular}{lcc}
\hline Siang & 15 & 13,9 \\
Sore & 12 & 11,1 \\
Lama paparan televisi & & 58,3 \\
$\leq 2$ jam/ hari & 63 & 41,7 \\
$\quad$ 2 jam/ hari & 45 & \\
Pengawasan orangtua & & 83,3 \\
Selalu & 90 & 11,1 \\
Jarang & 12 & 5,6 \\
$\quad$ Tidak pernah & 6 & \\
\hline
\end{tabular}

Tabel 3 Tabulasi silang antara lama paparan televisi dengan kemampuan motorik halus balita

\begin{tabular}{|c|c|c|c|c|c|c|c|}
\hline \multirow{3}{*}{$\begin{array}{c}\text { Durasi Paparan } \\
\text { Televisi }\end{array}$} & \multicolumn{4}{|c|}{ Perkembangan Motorik Halus } & \multirow{2}{*}{\multicolumn{2}{|c|}{ Total }} & \multirow{3}{*}{ Nilai $\mathrm{p}$} \\
\hline & \multicolumn{2}{|c|}{ Lulus } & \multicolumn{2}{|c|}{ Belum lulus } & & & \\
\hline & $f$ & $\mathrm{n}(\%)$ & $\mathrm{f}$ & $\mathrm{n}(\%)$ & $f$ & $\mathrm{n}(\%)$ & \\
\hline$\leq 2 \mathrm{jam}$ & 48 & 76,2 & 15 & 23,8 & 63 & 58,3 & 0,042 \\
\hline$>2$ jam & 26 & 57,8 & 19 & 42,2 & 45 & 41,7 & \\
\hline Total & 74 & & 34 & & 108 & & \\
\hline
\end{tabular}

* Uji chi-square

Tabulasi silang antara lama paparan televisi dengan kemampuan motorik halus tertera pada Tabel 2. Berdasarkan Tabel 2 didapatkan bahwa sebagian besar balita yang lama durasi menonton televisi $\leq 2$ jam/ hari dengan perkembangan motorik halus dan hasilnya lulus sebesar $76,2 \%$ dan yang menonton $>2 \mathrm{jam} /$ hari sebagian besar $57,8 \%$ lulus perkembangan motorik halus. Balita yang perkembangan motorik halus dalam kategori belum lulus persentarsenya lebih banyak pada balita yang lama durasi menonton televisi $>2$ jam/hari yaitu 42,2\%. Terdapat hubungan antara lama paparan televisi dengan perkembangan motorik halus balita usia 3-5 tahun $(\mathrm{p}<0,05)$ dengan kekuatan hubungan rendah $(0,192)$.

Berdasarkan hasil penelitian, sebagian besar responden yang menonton $\leq 2$ jam/ hari menunjukkan perkembangan motorik halus yang sesuai dengan usianya. Hal ini dapat terjadi karena adanya aktivitas lain yang dilakukan selain menonton televisi juga dibantu dengan peran aktif orangtua dalam menstimulasi anaknya. Keterlibatan orangtua dalam melakukan pengawasan terhadap aktivitas menonton televisi anak dapat mengurangi efek negative menonton televisi. Seperti yang disebutkan pada guideline yang dikeluarkan oleh AAP bahwa orangtua sebaiknya membatasi menonton tayangan televisi untuk 1 jam/hari dan mendampingi juga membantu anak mereka untuk memahami tayangan televisi yang sedang dilihat serta membantu anak-anak untuk menerapkan apa yang telah mereka pelajari di lingkungan sekitar mereka (American Academy of Pediatrics, 2016). Kemampuan 
motorik halus yang baik disebabkan karena adanya pengaruh dari tayangan televisi yang dilihat oleh anak. Kemampuan anak untuk mengaplikasikan pengetahuan yang didapat berbeda antara anak yang satu dengan yang lain. Semakin banyak hal baru yang dilihat dan didengar oleh anak, menumbuhkan rasa ingin tahunya. Karena motorik halus melibatkan kemampuan memegang dan memanipulasi benda-benda serta koordinasi mata dan tangan yang baik, anak-anak yang lulus perkembangan motorik halus ini mendapatkan stimulasi yang tepat dari orangtua dan kemampuan mental yang baik. Sedangkan responden yang menghabiskan waktunya untuk menonton televisi $\leq 2 \mathrm{jam} /$ hari sebanyak yang belum lulus perkembangan motorik sebanyak $23,8 \%$.

Sebagian besar dari responden yang belum lulus apek motorik halus ini, dapat dipengaruhi oleh faktor usia yang masih belum mencukupi untuk menguasai kemampuan motorik halus, juga faktor stimulasi dari orangtua yang kurang. Meskipun sebagian besar responden diasuh oleh orangtua, faktor pendidikan ibu juga sangat berpengaruh dalam tindakan stimulasi anak. Orangtua yang berpendidikan rendah memiliki pengetahuan yang berbeda dengan orangtua yang berpendidikan tinggi dalam cara mengasuh dan menstimulasi anak. Karena pengaruh kualitas pengasuhan dari orangtua yang tidak konsisten ditambah dengan tayangan yang kurang mendidik dapat berdampak negative terhadap kemampuan kognitif anak (Suryawan, 2017).

Orangtua melihat bahwa menonton televisi memiliki beberapa keuntungan, selain sebagai sarana edukasi pada anak juga dengan menonton televisi bias menenangkan anak yang rewel dan sebagai alat distraksi bagi anak ketika orangtua melakukan pekerjaan rumah. Akan tetapi sebagian orangtua menganggap bahwa menonton televisi dapat memberikan efek negative yaitu, konten siaran dan iklan yang tidak sesuai dengan usia anak, kecanduan akan tayangan televisi, selain itu dapat berpengaruh pada kehidupan sosial (Bentley, Turner, \& Jago, 2016). Dari $65,7 \%$ balita yang diasuh oleh ibunya $64,4 \%$ lulus perkembangan motorik halus. Adanya peran orangtua dalam menstimulasi perkembangan anak dengan ikut berinteraksi secara aktif dalam setiap kegiatan anak dengan ikut membatasi waktu menonton memberikan dampak yang positif bagi perkembangan anak. Bentuk dukungan dari orangtua kepada anaknya seperti memberi perhatian, bersikap 
hangat, bertutur kata dengan lembut, memberi respon positif akan pertanyaan dari anak juga terlibat dalam percakapan kecil yang melibatkan pertanyaan dan penjelasan, merupakan salah satu bentuk stimulasi yang diberikan orangtua kepada anak (Wooldridge \& Shapka, 2012).

\section{SIMPULAN DAN SARAN}

Lama durasi menonton televisi memiliki pengaruh terhadap perkembangan motorik halus anak usia 3-5 tahun. Semakin tinggi/ banyak lama durasi menonton televisi maka semakin besar peluang anak untuk mengalami kemungkinan penyimpangan perkembangan. Namun, dibutuhkan penelitian lanjutan untuk menggali lebih mendalam mengenai aktivitas yang dilakukan anak selain menonton televisi serta dengan umlah sampel yang lebih banyak dan meminimalisir faktor lain yang dapat menyebabkan bias.

\section{DAFTAR PUSTAKA}

American Academy of Pediatrics. (2016). Media and young minds, 138(5). https://doi.org/10.1542/peds.2016-2591

Bentley, G. F., Turner, K. M., \& Jago, R. (2016). Mothers' views of their preschool child' s screen-viewing behaviour: a qualitative study. BMC Public Health, 1-11. https://doi.org/10.1186/s12889-016-3440-z

Bruni, O. (2015). Impact of television on the quality of sleep in preschool children. Sleep Medicine. https://doi.org/10.1016/j.sleep.2015.06.005

Burki, T. K. (2018). In Focus TV advertising and childhood obesity in the UK. THE LANCET Diabetes \& Endocrinology, 8587(18), 30179. https://doi.org/10.1016/S2213-8587(18)30179-7

Cheng, S., Maeda, T., Yoichi, S., Yamagata, Z., \& Tomiwa, K. (2010). Early television exposure and children's behavioral and social outcomes at age 30 months, 20(Suppl 2), 1-2. https://doi.org/10.2188/jea.JE20090179

Cox, R., Skouteris, H., Aquila, D. D., Hardy, L. L., \& Rutherford, L. (2013). Television viewing behaviour among pre-schoolers : Implications for public health recommendations what is missing from current TV viewing, 49. https://doi.org/10.1111/jpc.12041

Daindo, N. S., Hariyanto, T., \& Adi W., R. C. (2017). Hubungan antara lama melihat tayangan televisi dengan perkembangan motorik halus pada anak usia pra sekolah di TK Bani ahmad Tlogo Indah Kecamatan Lowokwaru Malang. Nursing News Volume 2, 2017, 2(Nomor 3), 377-385

Duch, H., Fisher, E. M., Ensari, I., \& Harrington, A. (2013). Screen time use in children under 3 years old: a systematic review of correlates. International Journal of Behavioral Nutrition and Physical Activity, 10(1), 1. 
https://doi.org/10.1186/1479-5868-10-102

Fajariyah, S. N., Suryawan, A., \& Atika. (2018). Dampak penggunaan gawai terhadap perkembangan anak. Sari Pediatri, 20(2), 101-105

Kostyrka-allchorne, K., Cooper, N. R., \& Simpson, A. (2017). The relationship between television exposure and children' $\mathrm{s}$ cognition and behaviour: A systematic review. Developmental Review. https://doi.org/10.1016/j.dr.2016.12.002

Lin, L., Cherng, R., Chen, Y., \& Chen, Y. (2015). Effects of television exposure on developmental skills among young children. Infant Behavior and Development, 38, 20-26. https://doi.org/10.1016/j.infbeh.2014.12.005

Soetjiningsih. (2012). Tumbuh kembang anak. (I. N. G. Ranuh, Ed.) (Cetakan 20). Jakarta: EGC.

Soetjiningsih, \& Ranuh, I. N. G. (2016). Tumbuh kembang anak. EGC

Suryawan, A. (2017). Pengaruh gadget terhadap tumbuh kembang balita. In Update on Pediatric Diagnostic and Management Practices 2017 (pp. 86-98).

Wooldridge, M. B., \& Shapka, J. (2012). Journal of Applied Developmental Psychology Playing with technology: Mother - toddler interaction scores lower during play with electronic toys. Journal of Applied Developmental Psychology, 33(5), 211-218. https://doi.org/10.1016/j.appdev.2012.05.005 